\title{
Foresight wins bouquets and brickbats from watchdog
}

London. An all-party British parliamentary committee has sharply criticized the ways in which the government is implementing key recommendations of the white paper on science and technology, published in the summer of 1993.

The criticism comes in a report published last week by the House of Commons Select Committee on Science and Technology at the end of a three-month inquiry into the Technology Foresight programme, introduced by the government as a way of identifying strategic priorities for government spending on research.

The committee has high praise for the way the Foresight programme, which initially operated through 15 subject panels, was both conceived and put into practice. Indeed, it describes the completion of the first 'survey' stage of the programme, which involved polling both the academic and industrial research communities on future technological needs and opportunities, as "a remarkably impressive achievement".

"Technology Foresight is a good thing," says Gavin Shaw (Conservative, Pudsey), the chairman of the select committee. "We recognize that a tremendous amount of effort has gone into it, and the increase in awareness that has been the result."

Such comments reflect a widespread feeling in Campbell: seeking to the scientific com- protect basic research. munity that the

programme, after a somewhat bumpy start, has turned out to be more effective in promoting dialogue (and less rigid in imposing priorities) than many had feared. A recent report from the Royal Society, for example, points to what many consider to be one of its main achievements, namely the creation of active 'networks' connecting researchers to those potentially interested in implementing their results.

But the select committee. which effectively works as a parliamentary watchdog on British science policy, is still concerned about aspects of the critical next stage, the way in which the results of the programme are being put into practice.

For example, it reflects the fears of committee members such as Anne Campbell (Labour, Cambridge) that the government might use the Technology Foresight exercise to determine the research councils' spending priorities and increase the pressure on funds for basic research.
The committee's sharpest remarks pick up on comments made by, among others, the National Farmers' Union, on the absence of any life scientists from the revised membership of the Technology Foresight steering group, the body responsible for overseeing the development and implementation of the programme.

Admitting that the steering group cannot duplicate the sector panels, the committee nevertheless points out that "such a lacuna may prevent it from carrying out its oversight role effectively". Noting, furthermore, that none of the industrialists on the group comes from an industry which is based on the life sciences, it suggests that "serious consideration be given to adding someone with expertise related to the sector underpinned by biological science".

Government officials reject this criticism. They point out that individuals are appointed to the group in their own right, not as representatives of a particular discipline or interest group, and that the life sciences are not entirely absent, as the group is chaired by Robert May, the government's chief sci$₫$ entific adviser, who is a population ecologist.

But Shaw describes such a response as "a bit glib". He adds: "There is concern that the life sciences, which are an important part of the science base, have come out as a loser in this. We can only say we have taken note of that concern, and must monitor the situation to see what happens in practice."

The committee also has some harsh comments about what it perceives as the failure of the Office of Science and Technology to exert a stronger role in coordinating research policy across different government departments. In particular, it focuses on shortcomings in the publication of the Forward Look, an annual document on total government spending for research and development, promoted as the main vehicle for exercising such influence.

Referring, for example, to the lack of detail on topics such as the long-term science plans for various government departments, the committee says "this seems to be evidence that the transdepartmental coordination promised in the 1993 white paper is not working satisfactorily".

The government will, in due course, provide a detailed response to the select committee's comments. While accepting some of the detailed criticism concerning the lack of figures in the Forward Look, it is expected to defend itself against the broader charges, which many see as reflecting a long-held desire by the select committee for a more powerful role for science in Whitehall than other politicians may be prepared to accept.

David Dickson
East German scheme fails to rehabilitate university scientists

Munich. Only one in 20 of the 2,000 scientists from the former east German Academy of Sciences who had been promised permanent jobs in universities have actually been offered such positions, according to a survey conducted by the university teachers union, the GEW.

The researchers involved are those who had been earmarked for university posts by the Wissenschaftsrat, Germany's science council. The fate of the remaining scientists remains unclear, as the Bund-Länder Kommission (BLK), the body that mediates on research and education between federal and Länder governments, voted this week to delay until next spring any decision on new programmes that could provide further temporary support.

The scientists had been chosen from the thousands who lost their jobs when their research institutes or departments were closed after the reunification of Germany. The Wissenschaftsrat thought that transferring them to universities would help to solve a second post-reunification problem, namely the reintroduction into universities of research, which had been effectively banished into academy institutes during the communist years.

As a result, the federal and Länder governments jointly set up a five-year, DM600-million (US\$414-million) programme, known as the WissenschaftlerIntegrationsprogramm (WIP), to support the scientists while they found new positions.

But the programme, which runs out next year, has not worked. The universities had already been forced to dismiss many of their own staff as a result of the 'restructuring' process introduced after reunification, and were reluctant to take on 'outsiders'. About a quarter of those originally recruited into the WIP scheme dropped out, and most of the rest now have no hope of a university position. The federal government continues to insist that the WIP programme will not be extended.

At a meeting organized by the GEW in Berlin last week, the governments of four of the new Länder announced that they would provide additional short-term research funds to support their own WIP scientists beyond 1996. Gerd Köhler, a member of the GEW committee for universities and research, said the union would monitor the schemes to ensure that all WIP scientists continued to be suitably employed.

But the union is not insisting that WIP scientists be integrated into universities. That demand has been made only by Berlin, where more than a third of all WIP scientists are employed, and which has the most severe financial 


\section{Japan's Diet eyes technology assessment}

Tokyo. A committee with broad powers to analyse government science policy and provide advice to lawmakers on science and technology is to be set up in Japan if a bill to be put before the Diet, Japan's Parliament, early next year is approved.

The bill has been proposed by Taro Nakayama of the Liberal Democratic Party (LDP). The proposed committee - tentatively called the Science and Technology Assessment Committee - would be made up of 15 Diet members from all political parties, each of whom would serve a threeyear term, supported by an office staffed by an estimated 105 researchers.

This office is expected to have a budget and management structure modelled on that of the US Office of Technology Assessment (OTA) which, ironically, was abolished by Congress earlier this year after 22 years (sce Nature 376, 541; 1995).

Nakayama's proposal comes at a time when mounting political support for science and technology, spurred by continuing recession and fears that Japan may be left behind in key areas, has already resulted in a flurry of new legislation and other measures designed to bolster the country's position in high technology.

Nakayama himself is a qualified medical doctor and a former diplomat. He proposed the new bill as a representative of the Diet's Science, Technology and Policy Committee. He and others say the new assessment committee is needed because of the increasing scale and complexity of governmentsupported science projects, and the lack of a body capable of assessing their benefits and effectively coordinating the expenditure of public funds on research and development.

Nakayama, for example, wanted to cut funding for Japan's nuclear-powered ship Mutsu, which consumed more than a billion dollars of taxpayers' money over nearly two decades yet spent only a few days at sea. But there was no adequate mechanism for the Diet to cut off funding, while the Science

\section{problems of all the new Länder.}

Manfred Erhardt, the city's research minister, told the meeting that the WIP programme should be extended to buy more time to achieve the original intention of genuinely integrating the scientists into universities. The University Rectors' Conference (HRK) supports this position, but has no direct say in decision-making.

Some new money earmarked for east German researchers, including WIP scientists, could be made available if plans come to fruition for a third Hochschulsonderprogramm, a trouble-shooting programme aimed at solving particular universityrelated problems, such as the low representation of women in academic institutions.

In principle, all sides agree that such a and Technology Agency continued to pour money into the project as it did not want to lose the budget.

Details of the proposed committee's priorities have not been made public, But areas within its remit are expected to include the nation's space and faster breeder reactor programmes which some believe have not been adequately assessed.

According to one of his political colleagues, Nakayama feels that Japan is wasting a lot of money on the $\mathrm{H}-2$ rocket, which costs twice as much as launch vehicles elsewhere. He thinks Japan should consider using cheaper Chinese or Russian rockets to launch Japanese satellites.

The latest proposal follows last month's approval of a law on basic science and technology passed by the Diet in the belief that the government should do more to support basic research, particularly that which may sow the seeds of future industrial technologies in areas such as materials and biotechnology (see Nature, 378, 227; 1995).
Nakayama originally wanted to pass both the basic science law and the present bill as a package, and is said to have been extremely angry when the basic science law was passed first. Both this law and the latest proposal originated as private members' bills drafted by members of the LDP, some of whose younger members in particular appears to be keen supporters of science and technology (see Nature 378, 8; 1995).

The main body responsible for providing the Japanese cabinet with advice on science and technology at present is the Science and Technology Council. This is a mixture of academics and politicians, and includes the ministers from all government departments and agencies responsible for supporting science, chaired by the prime minister.

But although the membership of these ministers and the prime minister lends the group an apparent authority, many inside and outside the government feel the council is not as influential as its prestige suggests.

Stephen Barker

\section{UK geophysicist killed in San Diego}

San Diego. Keith Runcorn, a British geophysicist who was widely known for his work on continental drift, was strangled in his hotel room in San Diego, California, last week while on a lecture tour. San Diego police have made no arrests in the murder of Runcorn, who held an endowed chair at the University of Alaska in Fairbanks.

In the 1950 s, Runcorn was an carly proponent of the theory that continents slowly drift apart, gradually altering the map of the world. Plate tectonics, as the theory became known, revolutionized geology, spurring him and other geophysicists to debate for decades the merits of the concept.

Runcorn later worked with Patrick (later Lord) Blackett at the University of Manchester, before returning to the University of Cambridge. He also carried out research

programme is needed, particularly to help iron out inequalities between east and west Germany. But at its meeting this week, the BLK was unable to decide how much money the programme should have, and how the bill should be split between federal and Länder governments. It therefore delayed a decision until next March.

The federal government would like the total cost to be DM3.6 billion and wants the Länder to pay 60 per cent, but the Länder would like a total of DM4.1 billion, split 50:50. Moreover, the federal government argued that the final decision will depend on the outcome of other contentious issues, such as how much money it will have to spend on student grants and university buildings.
Alison Abbott on remnant magnetism, at the University of Newcastle upon Tyne.

A scientist who thrived on controversy, the red-haired Englishman was a member of the committee that monitored Biosphere 2, the experimental habitat near Tucson, Arizona, that doubles up as both a research project and a tourist attraction. $\mathrm{He}$ was meeting academic colleagues in San Diego, Los Angeles and San Francisco on the trip when he was killed.

Runcorn was staying in downtown San Diego, in a hotel which is sur- Runcorn: thrived on rounded by new scientific controversy. office towers and plush hotels with stunning views of San Diego Bay. According to police, he had checked into the older, refurbished hotel in order to save money and be near restaurants and shops, and had planned to stay there a week.

Police said he had a blunt-trauma wound to the head, and had also been strangled. Runcorn's room was partially ransacked, and he is thought to have been dead for a number of hours before being found.

The neighbourhood is not known for serious crime, and tourists walk the area at all hours. Murders of such prominent individuals are rare in San Diego, where most killings are related to gangs or the drug trade the flourishes near the border with Mexico.
Rex Dalton 